\title{
Community engagement in SGBV prevention and response: A compendium of interventions in the East and Horn of Africa and the Great Lakes region
}

Zahra Mirghani

Joanina Karugaba

Nicholas Martin-Achard

Chi-Chi Undie

Population Council

Harriet Birungi

Population Council

Follow this and additional works at: https://knowledgecommons.popcouncil.org/departments_sbsr-rh

Part of the Demography, Population, and Ecology Commons, Family, Life Course, and Society Commons, and the International Public Health Commons How does access to this work benefit you? Let us know!

\section{Recommended Citation}

Mirchani, Zahra, Joanina Karugaba, Nicholas Martin-Achard, Chi-Chi Undie, and Harriet Birungi. 2017. "Community engagement in SGBV prevention and response: A compendium of interventions in the East and Horn of Africa and the Great Lakes region." Nairobi: Population Council. 


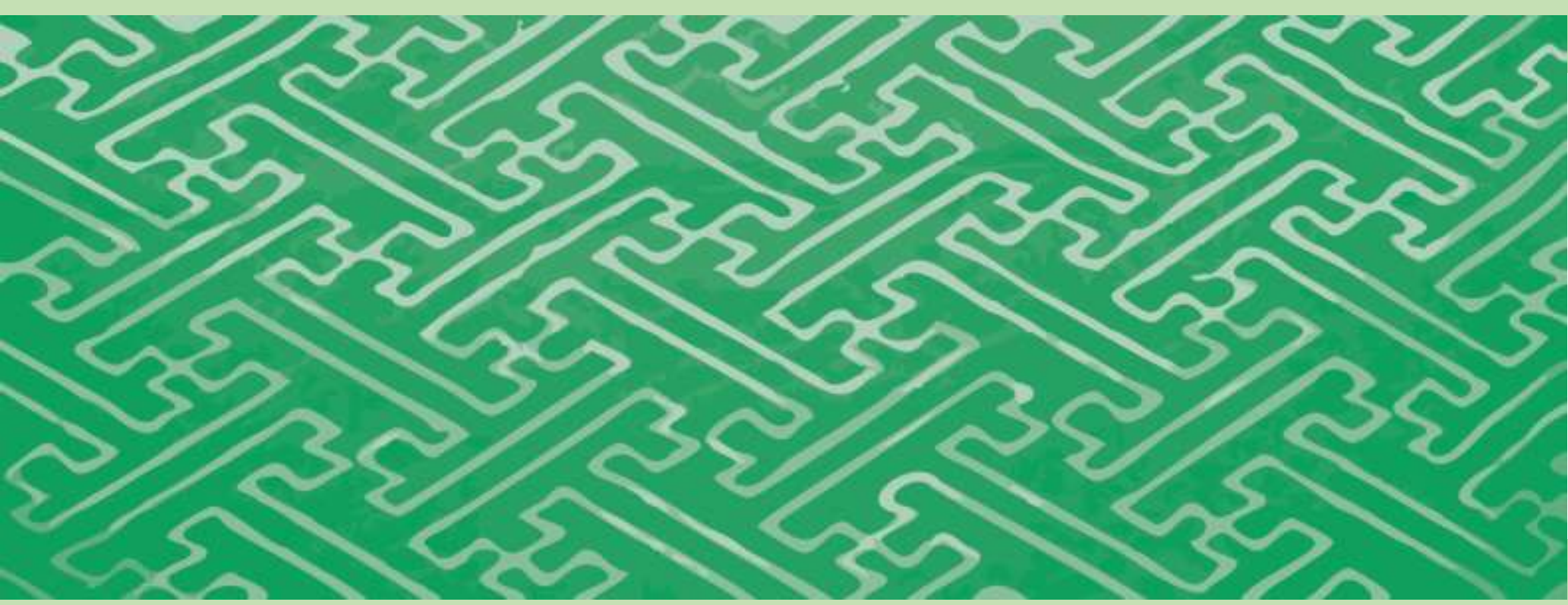

\section{COMMUNITY ENGAGEMENT IN SGBV PREVENTION AND RESPONSE}

A Compendium of Interventions in the East \& Horn of Africa and the Great Lakes Region

Zahra Mirghani, Joanina Karugaba, Nicholas Martin-Achard UNHCR

Chi-Chi Undie, Harriet Birungi

Population Council 


\section{(8)(ii) UNHCR \\ Haut Commisseriat des Nations Lhes pour ies stigies}

The UN Refugee Agency (UNHCR) is the United Nations programme mandated to provide international protection and support to refugees. In line with this mandate, UNHCR is committed to ending all forms of SGBV in humanitarian settings. UNHCR works alongside displaced communities and with different partners across a wide range of sectors to prevent SGBV and to ensure support is available for survivors.

\section{POPULATION \\ COUNCIL \\ Ideas, Evidence, Impact.}

The Population Council confronts critical health and development issues - from stopping the spread of HIV to improving reproductive health and ensuring that young people lead full and productive lives. Through biomedical, social science, and public health research in 50 countries, we work with partners to deliver solutions that lead to more effective policies, programs, and technologies that improve lives around the world. Established in 1952 and headquartered in New York, the Council is a non-governmental, non-profit organization governed by an international board of trustees.

Suggested citation: Mirghani Z., Karugaba J., Martin-Archard N., Undie C., and Birungi H. 2017. Community Engagement in SGBV Prevention and Response: A Compendium of Interventions in the East \& Horn of Africa and the Great Lakes Region. Nairobi, Kenya: Population Council.

@2017 The Population Council Inc. 


\section{TABLE OF CONTENTS}

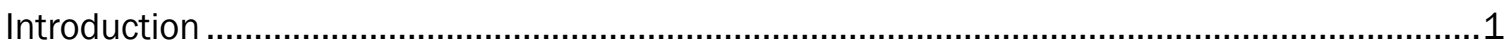

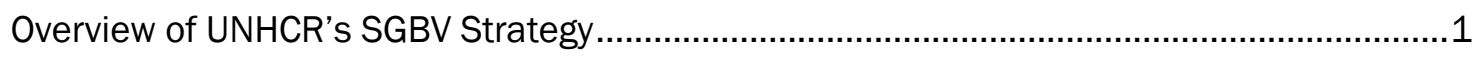

Community-Based Approach to SGBV Prevention and Response ......................................

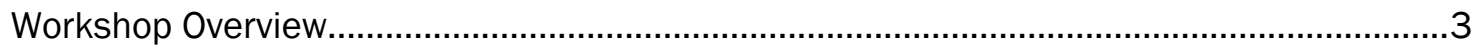

Community Engagement in SGBV Prevention and Response: A Compendium of

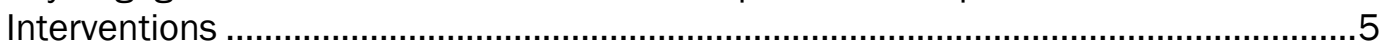

Prevention, Identification, and Response to SGBV ............................................................

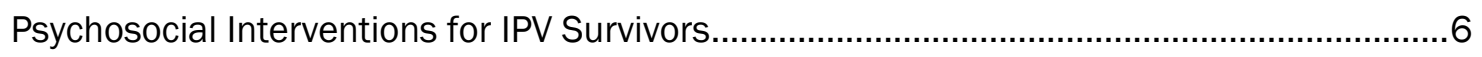

Youth Pyramid Structure ...........................................................................................

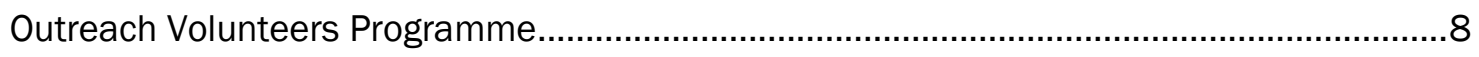

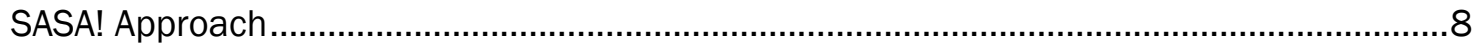

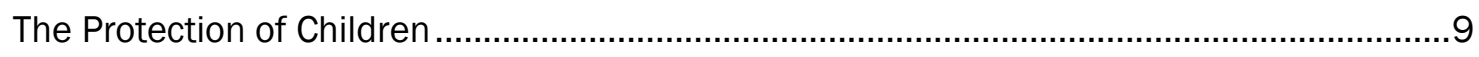

Protection Learning Programme - Anti-FGM Initiative ................................................

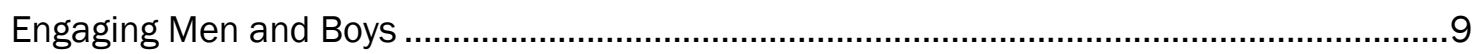

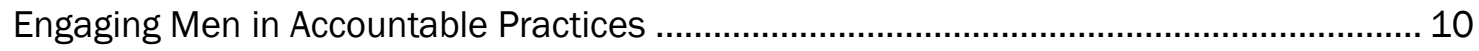

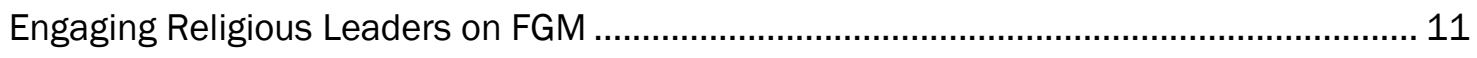

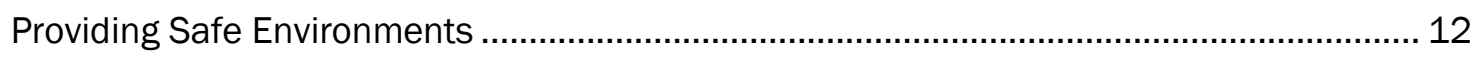

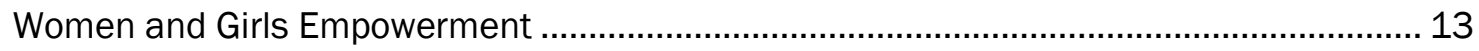

Guidance for Effective Adoption of Community Engagement in SGBV Protection

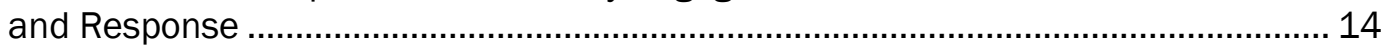

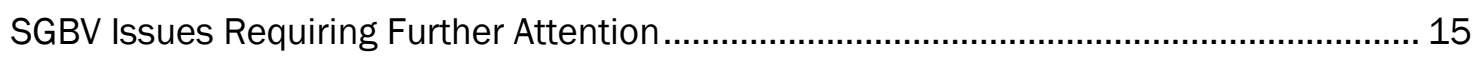

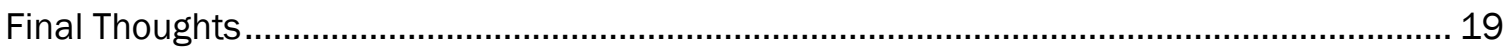

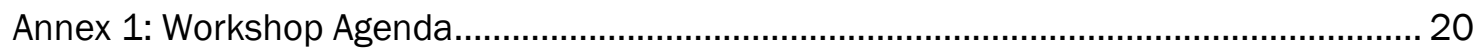

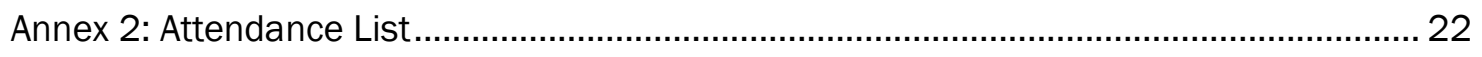

Annex 3: Compendium of SGBV Protection and Response Approaches .............................. 24

Annex 4: Possible Areas of Interest for Anti-SGBV Initiatives............................................... 26 


\section{INTRODUCTION}

This document captures efforts by UNHCR and its partners in promoting community engagement in combating sexual and gender-based violence (SGBV) in the region. The compendium of tools reflected here is drawn from the responses of several actors to various forms of SGBV. The diversity of these efforts involves a range of demographic groups (in terms of gender and age), geographic contexts (rural, urban), and intended outcomes (SGBV prevention, response, or both). The interventions described are also at various stages of development or maturity, and varied in scope, with a few having been properly documented and assessed in humanitarian settings. A review of these approaches provides important insights, and highlights opportunities for strengthening programming. It is hoped that this compendium will enhance advocacy for further support, and lead to greater and more sustainable impact.

\section{Overview of UNHCR's SGBV Strategy}

Conflicts and natural disasters create conditions where women, men, girls and boys are vulnerable to Sexual and Gender-Based Violence (SGBV). SGBV includes acts or threats of acts which inflict physical, mental, or sexual harm or suffering, or related deprivations of liberty on the basis of gender. SGBV can have severe and long lasting consequences for survivors, their families and societies. At the level of the survivor, immediate health consequences include reproductive health impacts, injury, and a myriad of other negative effects which may even lead to death.

SGBV is a violation of the human rights of those against whom violence is perpetrated. UNHCR adopts a rights-based approach in its efforts to prevent and respond to SGBV. These efforts include advocacy and programmatic interventions highlight and protect the rights of refugees, minimize the risk and exposure of refugees to SGBV and to maximize recovery from SGBV. Notably, UNHCR has elaborated a specific strategy for action (updated in June 2011) against SGBV in humanitarian settings. The strategy includes recommended actions in three focus areas, in order to strengthen UNHCR's capacity and expertise in addressing SGBV:

1) Data collection and analysis: Improve the quality of programmes by adopting and maintaining appropriate SGBV data collection and analysis tools and working with institutions and partners on researching and documenting SGBV. 
2) Knowledge management and capacity-building: Strengthen the management of SGBV programmes by investing in capacity-building and expertise across the organisation.

3) Partnerships and coordination: Working with UN agencies, governments, non-governmental organisations (NGOs) and displaced communities, strengthen SGBV prevention, response and coordination

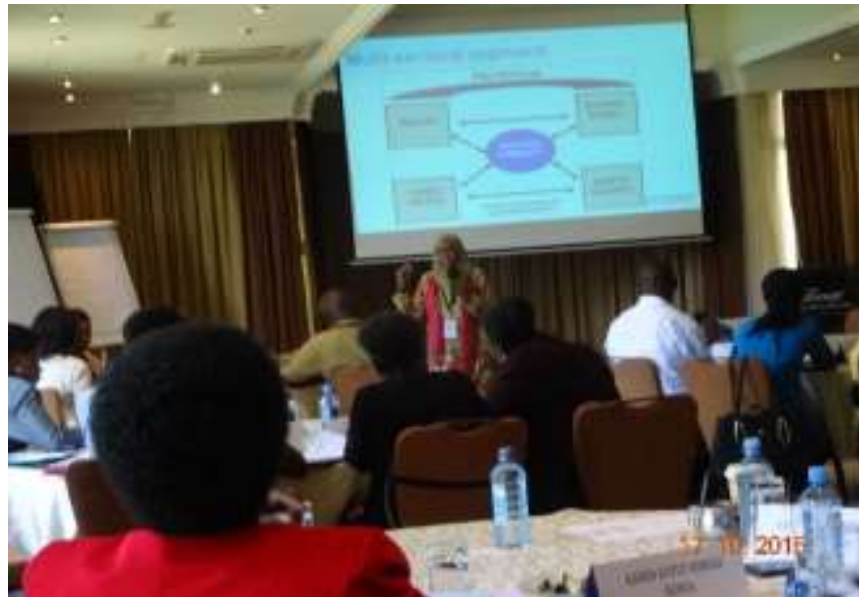

Zahra Mirghani, setting the stage. mechanisms for effective service delivery.

\section{Community-Based Approach to SGBV Prevention and}

\section{Response}

UNHCR adopts a rights-based approach to its work with persons of concern. These rights include the right of every person to participate in deciding and shaping their lives. Through the application of an Age, Gender and Diversity Approach (AGD) UNHCR aspires to ensure that these rights are accessible to all persons of concern on an equal footing. In addition, UNHCR recognizes that external input alone cannot deliver sustainable results for persons of concern. Protection and response strategies are more effective when they are designed, implemented and monitored with the meaningful engagement of refugees in all stages of the process. The community-based approach is therefore an integral aspect of the UNHCR framework for action on SGBV.

The approach shifts the focus from individual service delivery to enhancing the capacities of people of concern and their communities to be active agents in their own protection. By so doing, protection strategies are improved and people of concern are recognized as resources and rightsholders, rather than as passive beneficiaries of services. 


\section{Workshop Overview}

With this background in mind, the UNHCR Regional Services Center in Nairobi and the Population Council convened a dissemination workshop entitled Engaging Communities in SGBV Prevention and Response in Humanitarians Settings (see Annex 1 for workshop programme). The meeting served as a platform for sharing and learning from regional initiatives introduced to boost community engagement in SGBV protection and to reduce the occurrence and consequences of

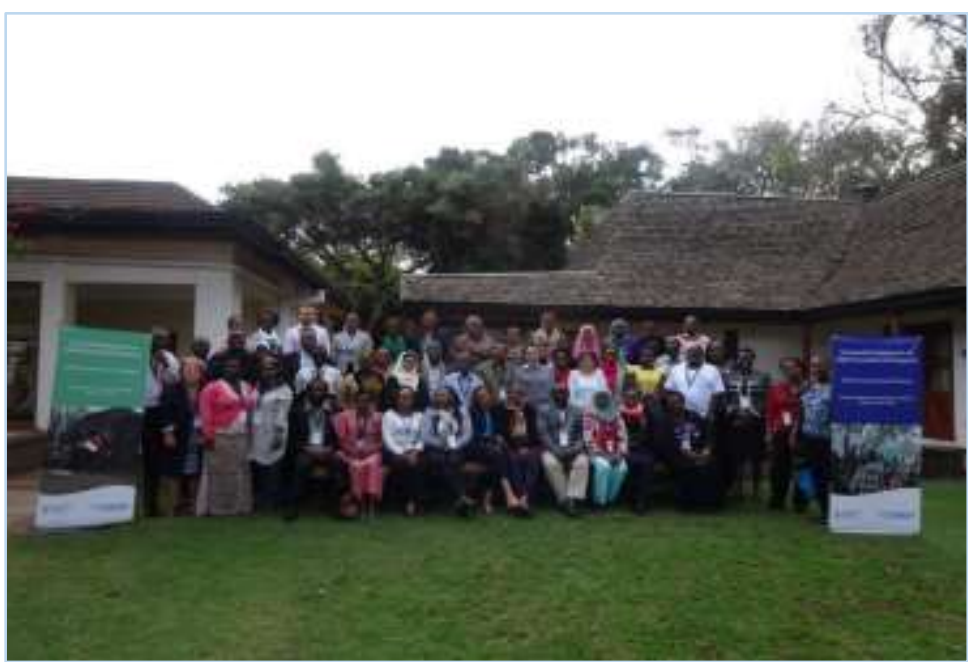

Meeting participants in Nanyuki, Kenya.

SGBV in humanitarian settings. The meeting took place from 17 to 19 October, 2016 in Nanyuki, Kenya. Approximately 50 experts participated in the workshop, comprising SGBV focal points from UNHCR as well as national and international NGO staff. A total of 13 countries in the region were represented (see Annex 2 for details of participants). The objectives of the workshop were to:

- Take stock of, and reflect upon, the various community-based SGBV initiatives applied in UNHCR's field operations;

- Promote the utilization of new, evidence-based SGBV initiatives in UNHCR's programming;

- Strengthen promising field initiatives by enhancing understanding of principles of effective community engagement; and

- Strengthen and facilitate regional technical exchange and information-sharing around community engagement in SGBV among UNHCR and partners.

As the prevention of, identification of, and response to, SGBV are noted as cross-cutting strategies in UNHCR's action plan, the workshop centered on initiatives related to these areas. In addition, the workshop focused on 5 out of 6 action areas identified by UNHCR to enhance the quality of protection and improve services for specific at-risk populations from 2011-2016. The specific action areas highlighted during the workshop include:

- The protection of children (which includes the prevention of and responses to sexual violence and harmful traditional practices, such as early marriage);

- Addressing survival sex as a coping mechanism;

- Engaging men and boys;

- Providing safe environments and access to domestic energy;

- Protecting LGBTI persons of concern.

The remainder of this report delves into a description of recent UNHCR interventions geared toward: 1) the prevention, identification, and/or response to SGBV, and 2) addressing UNHCR's identified action areas for selected at-risk populations. It is noteworthy that specific action areas for which there were no actual programming examples presented at the workshop (i.e., 
'Addressing survival sex as a coping mechanism' and 'Protecting LGBTI persons of concern') are not highlighted in the compendium of interventions. However, these topics were addressed at the workshop through sensitization presentations by UNHCR (see Annex 1 for the Meeting Agenda). Furthermore, interventions around these areas do exist in UNHCR's Kenya Operation, for instance. 


\section{COMMUNITY ENGAGEMENT IN SGBV PREVENTION AND RESPONSE: A COMPENDIUM OF INTERVENTIONS}

In response to the need for a community-based approach which undergirds UNHCR's strategy for action against SGBV, UNHCR and its partners have devoted efforts to developing (or adapting) and implementing innovative approaches to community-based SGBV prevention and response. ${ }^{1}$ These approaches include a variety of evidence-based and untested (yet, promising) interventions. This compendium showcases a mix of tested and untested models.

\section{Prevention, Identification, and Response to SGBV}

\section{Routine Screening for SGBV in Health Facilities}

A growing body of evidence points to the utility of routine screening for promoting the identification of SGBV survivors as well as survivors' access to comprehensive services.

Routine screening involves training health providers to ask clients about their SGBV experiences in an appropriate manner, and to offer supportive refers for further care. In collaboration with UNHCR, Africa Humanitarian Action, and the Office of the Prime Minister, this intervention was tested ${ }^{2}$ by the Population Council in Rwamwanja Refugee Settlement, Uganda, from 2015 to 2016.

Research results confirmed that routine screening for SGBV can be carried out successfully in humanitarian settings - particularly where screening implementation and SGBV response services are co-located. Survivors demonstrated willingness to disclose SGBV (including intimate partner violence [IPV] and non-partner sexual violence); health providers achieved high rates of screening, survivor detection, and survivor referral; most survivors adhered to their referrals; and survivors and providers alike expresses high satisfaction with the screening process.

As a testament to the effects of a community-based approach, which views community members as resources, female SGBV survivors recommended that the screening intervention be adapted to identify and respond to male perpetrators of SGBV. They also recommended other forms of male involvement, including male-targeted community outreaches, to ensure that male intimate partners also receive SGBV information as a preventive measure. Routine screening for SGBV has since been institutionalized in Rwamwanja Refugee Settlement, within the reception center and certain clinics in Rwamwanja. Several operations have also requested support for the roll-out of the intervention.

Challenges around referral adherence may occur, but can be resolved by ensuring that SGBV screening interventions are confined to health facilities in which SGBV services are available and therefore convenient for survivors to access.

\footnotetext{
1 These approaches are summarized in Annex 3.

2 Further information on this intervention and its evaluation may be found here: http://www.popcouncil.org/uploads/pdfs/2016RH ScreeningSGBV-Uganda.pdf.
} 


\section{Psychosocial Interventions for IPV Survivors}

Sexual violence can have a range of consequences for survivors, their families, and communities, including psychosocial consequences. The latter may include distress conditions such as fear, anger, shame, sadness and guilt; anxiety related disorders; depression and suicidal tendencies; and substance use disorders. Indeed, intimate partner violence (IPV), which is chronically underreported, can be revealed through these effects. These effects can be exacerbated by conditions in humanitarian contexts. Refugees in protracted situations are therefore vulnerable to a variety of mental health issues.

In response to these realities, UNHCR is employing a public heath approach to break the cycle of IPV and mental health problems by addressing both components simultaneously. This two-year project aims to develop and test an integrated intervention approach to reduce IPV and improve wellbeing among refugee women experiencing psychological distress in Tanzania and the Democratic Republic of Congo (DRC). Funded by DFID and UNHCR, the research is being carried out in cooperation with UNHCR, Johns Hopkins University, Muhimbili University (MUHAS), and the International Rescue Committee (IRC).

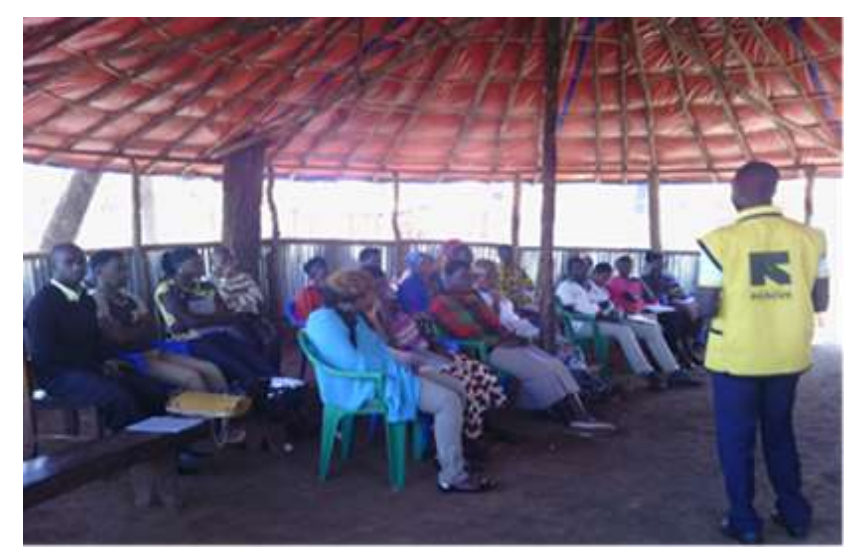

Community Advisory Board (CAB) Tanzania, PPS project, An integrated Intimate Partner Violence \& Mental Health Program, Nyarugusu Camp, Kasulu, Tanzania
The first component of the intervention incorporates an empowerment focus. UNHCR provides information to enable women to make safe and informed choices to reduce IPV. Secondly, the approach includes a psychological intervention which takes two forms: cognitive processing therapy (CPT) - an evidence-based, a manualized therapy, used by clinicians to address post-traumatic stress disorder (which is not uncommon among SGBV survivors) and related conditions - and cognitive behavioral therapy (CBT), a talking therapy used to treat depression and

anxiety by helping survivors change the way they perceive their situations. The research involves a randomized controlled trial among 400 women.

Communities play an integral part in the implementation of the project. For instance, in DRC, a community advisory board comprising religious leaders, social workers, traditional healers, nurses, and community and village leaders from the refugee community, regularly gave input into the implementation of the project.

Initial programmatic findings indicate that women are willing to answer sensitive questions related to IPV and mental health. Project findings also demonstrate prevalence of mental health problems in women affected by IPV, the most prevalent being stress, sadness and fear. The psychosocial approach yields promising results by reducing post-traumatic stress symptoms (including depression and anxiety) and improved functioning through group therapy. Overall, results indicate that the psychosocial approach holds promise as a approach to communitybased therapy for SGBV survivors. The group cognitive processing therapy approach was successfully modified to enable community-based paraprofessionals (psychosocial assistants) to 
provide the required therapy. This renders the approach particularly feasible in humanitarian contexts.

Some limitations associated with the intervention include the fact that short term therapies may not be effective for populations exposed to recurring trauma/multiple incidents. Secondly, a considerable amount of support is required by psychosocial assistants in order to effectively address survivors' needs. However, non-specific counseling is the current standard of care in health facilities. An evaluation of the intervention is underway.

\section{Youth Pyramid Structure}

Young people constitute a large proportion of the population in refugee setting, and their lives are not untouched by SGBV. The Youth Pyramid Structure is a community-based intervention which positions youth as change agents. The model, developed by the Lutheran World Federation, empowers community members to realise their potential to identify SGBV problems and devise sustainable solutions through youth-led anti-violence activities. The intervention has been implemented in Adjumani Settlement in Uganda, in close partnership with implementing and operating organisations, as well as local government.

In Adjumani, youth constitute more that $50 \%$ of the refugee population. Young people between the ages of 15 and 35 years also form the majority of potential SGBV penetrators and survivors alike. The Youth Pyramid Structure therefore involves training one young person to reach out to the community by going doorto-door with SGBV messages which target men, women, boys, and girls. The trained youth subsequently trains 2 others in his/her circle of influence. This carries on, creating critical mass of young anti-SGBV activists who reach out to their community

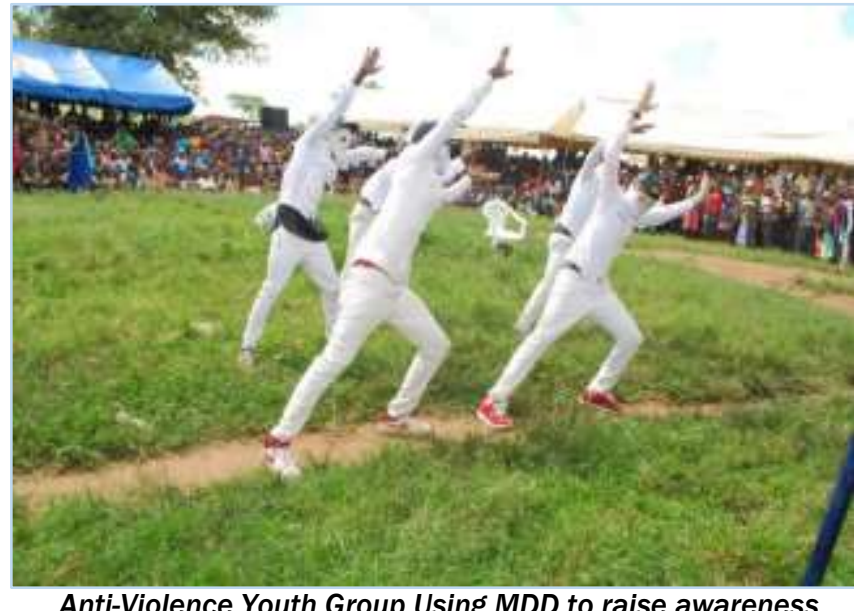

Anti-Violence Youth Group Using MDD to raise awareness on SGBV members. These young activists are organized in a 'pyramid' structure at village, zonal and settlement levels. At each level, a contact person is designated to link community members to SGBV service providers.

Anti-violence activities led by the youth activists include SGBV awareness creation; providing psychosocial support to survivors; promoting immediate reporting of violence using music, dance and drama (MDD); and prevention efforts (e.g., through self-defense lessons).

Programme data suggest that the model holds promise for contributing toward reduced GBV incidence, increased case reporting, and increased community participation. 


\section{Outreach Volunteers Programme}

Implemented among urban refugees in Nairobi, Kenya, the Outreach Volunteers Programme provides community-based volunteer groups with skills in SGBV awareness-raising. Volunteers draw on different psychological approaches are applied to support those affected by SGBV, including individual counselling for survivors, and roundtable dialogues for partners, guardians, and minors.

An initial 5 volunteers are identified and trained as peer educators on SGBV prevention and response. Efforts are made to identify and train SGBV survivors or caregivers of survivors in particular. These peer educators work as volunteers, but with technical and financial support for their respective activities. Each is tasked with identifying 5 more volunteers who are also trained. The 10 trained volunteers are then asked to find 15 more people within the community who are also trained and released to work within the community. The cycle of volunteer identification and training takes 3 months.

Programme observations suggest that, as a result of the Outreach Volunteers Programme (which relies on volunteers embedded in the community), more SGBV cases are identified and assisted, referral systems are clearer and more accessible to the community, and community support to survivors (including male survivors) is improved by reducing stigmatization.

\section{SASA! Approach}

SASA! is an evidence-based, community mobilization and prevention approach for addressing SGBV and HIV. ${ }^{3}$ 'Sasa' means 'now' in Kiswahili, emphasizing the urgent need to foster SGBV prevention in communities. The term 'SASA' is also an acronym representing the phases of the approach: Start, Awareness, Support, Actions.

The 'Start' phase involves pre-contemplation - a process by which community members begin to understand SGBV and HIV as interconnected issues through open and frank conversations. Through this process, the community identifies the power within itself to stop SGBV. This makes way for the 'Awareness' phase - a phase of contemplation - during which the community works to raise SGBV awareness levels. The 'Support' phase follows, and is characterized by preparation for action: community members learn how to support those affected by violence during this phase. The 'Actions' phase is the final stage of the SASA! intervention. It involves action and maintenance, with the community taking action to create and sustain change.

Each phase of the SASA! model takes the community through a one-year training based on documented, comprehensive toolkits which can be customized. The whole cycle takes 4 years to complete. In addition to training, results are accomplished through local activism, media and advocacy, and IEC materials.

The model is unique in its focus on power within the community to transform gender relations through positive, benefit-based programming. The SASA! model is growing in its prominence among humanitarian actors, and to date has been implemented in a number of operations in the region.

\footnotetext{
${ }^{3}$ Further information about SASA! may be found here: http://raisingvoices.org/sasa/download-sasa/.
} 


\section{The Protection of Children}

\section{Youth Engagement in SGBV Prevention and Response}

In addition to serving as a transit point for migrants, Shagarab Camp in Eastern Sudan receives a large number of children and unaccompanied minors arriving mainly from Eritrea and Ethiopia. Early marriage and FGM are widely practiced by the resident populations. This UNHCR initiative engages young people as a means of intervening early in the lives of persons of concern in order to effectively address SGBV. The initiative has involved training a group of 20 young men and women on FGM, child marriage, and child protection-related issues. In collaboration with social workers drawn from implementing partner organizations, the members of the trained youth group then participate in activities to facilitate awareness-raising sessions, among women and fellow youth in their respective camps. To date, the initial group of 20 young people has successfully reached 100 community members with key prevention messages around FGM and child marriage, as well as with information on child protection. These awareness-creation activities are expected to contribute to SGBV prevention and response.

\section{Protection Learning Programme - Anti FGM Initiative}

UNHCR is implementing an anti-FGM initiative in Hagadera Refugee Camp in Dadaab, Kenya. The population within this camp is primarily Somali, and the prevalence of FGM is at $95 \%$.

Distinguishing factors of the anti-FGM initiative in Hagadera include the involvement of religious leaders, the integration of FGM advocacy into other projects, and greater focus on fostering community engagement within the project through community dialogue sessions. A key component of the initiative is the establishment of stakeholder groups within the community, including a women leaders' forum and anti-FGM committees. Other important features include referrals for counselling and medical support, and linking of FGM victims into income generating activities.

The approach is yet to be documented and assessed. However, anecdotal evidence suggests that community conversation sessions in recognition of FGM as a health hazard have had a positive effect. Some complexities to be addressed emerge include the fact that FGM is a source of livelihood for some elderly women in the refugee camps. This reality hampers efforts to eradicate the practice. An unresolved question is whether to de-incentivize FGM practitioners by providing them with alternative income generating opportunities, or to prosecute them, given the legal provisions in Kenya for responding to FGM.

\section{Engaging Men and Boys}

\section{The 'Zero Tolerance Village Alliance' Model}

Pioneered in rural South Africa by the Thohoyandou Victim Empowerment Programme, the 'Zero Tolerance Village Alliance' (ZTVA) model is an intensive community-mobilization intervention geared toward community-led and community-owned SGBV prevention and response. Founded on the concept that communities have agency to change norms relating to SGBV, the ZTVA intervention is designed to inspire communities to brand themselves as 'zero tolerance' zones in regard to SGBV. The branding process involves a demonstration of motivation and commitment by the communities concerned. A critical mass of male and female community members are obligated to undergo a series of training sessions and to meet various criteria that grants them 
entry into an alliance of other like-minded communities that take a public stand against SGBV. Intervention activities include educational workshops, dialogues, and campaigns within communities, and culminate in a male pledge-taking ceremony (against SGBV), during which awards are also given to male and female community members who have displayed courage with regard to SGBV incidents in the community. Fostering such 'zero tolerance' communities is designed to change social norms around violence, leading to violence prevention and increased SGBV reporting and service-seeking by survivors.

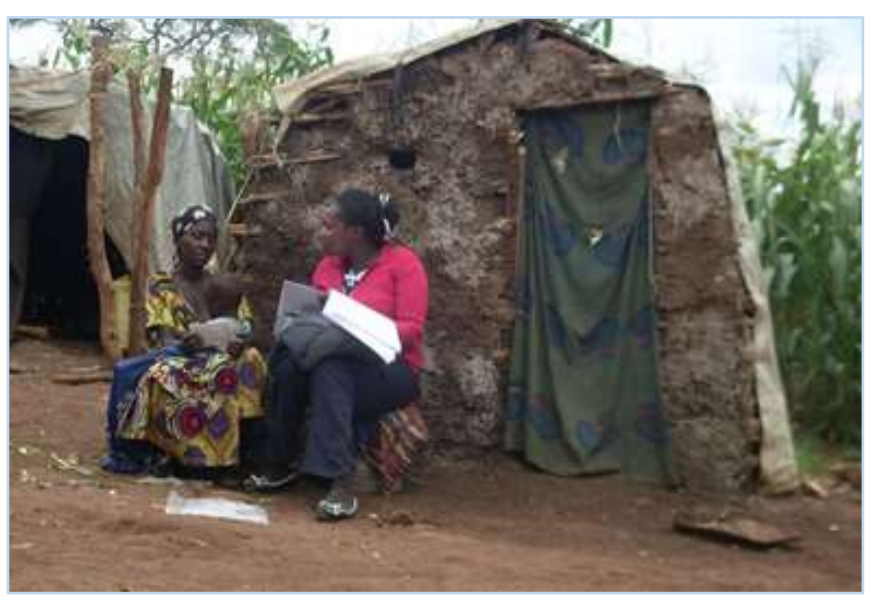

Engaging with community member in Rwamwanja
In collaboration with UNHCR, the Population Council evaluated the effectiveness of the ZTVA model in a humanitarian setting for the first time from 2015-2016. The model was implemented by the Lutheran World Federation in Rwamwanja Refugee Settlement (Uganda) with technical support from TVEP. Evaluation results ${ }^{4}$ confirmed the effectiveness of the model in increasing awareness of SGBV interventions; moderating negative gender attitudes and beliefs related to

SGBV; engendering more comprehensive knowledge of rape; reducing the occurrence of physical IPV (for men and women), sexual IPV (for men), non-partner physical violence (for men and women), and non-partner sexual violence (for women); and positively changing perceptions of community SGBV norms. The intervention had a short implementation period of six months. With a longer implementation period, it is likely that other indicators (e.g., male attitudes toward women's sexual autonomy in intimate partnerships, and the occurrence of sexual IPV in women) could also demonstrate positive shifts. Several operations have requested support for the roll-out of the intervention.

\section{Engaging Men in Accountable Practices}

Men have an important role to play in preventing SGBV, and gender transformative tools are key in challenging deep-seated beliefs held by men, as well as power structures which facilitate men's abuse of women. Drawing on gender transformative tools, the Engaging Men in Accountable Practices (EMAP) model ${ }^{5}$ was developed by IRC and implemented in cooperation with UNHCR and other actors.

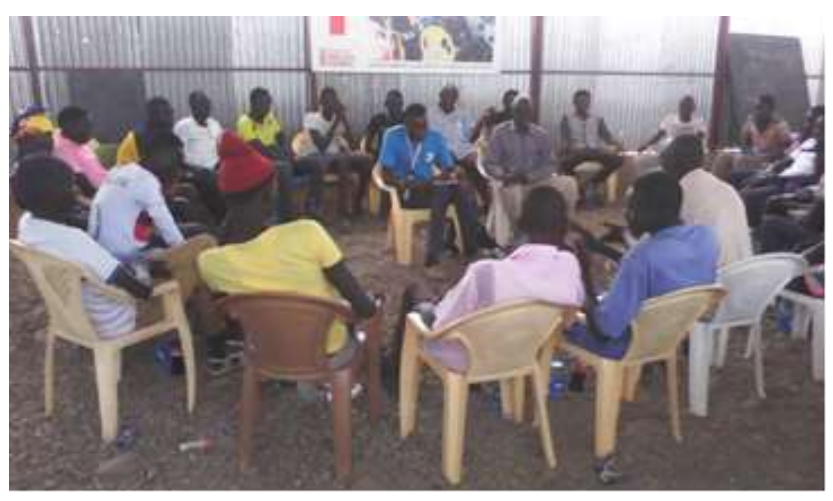

Young males and their role models engaged in discussions about gender equality

\footnotetext{
${ }^{4}$ Further information on this intervention and its evaluation may be found here: http://www.popcouncil.org/uploads/pdfs/2016RH_SGBVPreventionUgandaZTVA.pdf.

${ }^{5}$ Further information on this intervention may be found here: http://www.fsnnetwork.org/sites/default/files/IRC-EMAP-Introductory-Guide-High-Res\%20\%281\%29.pdf and here: http://www.fsnnetwork.org/sites/default/files/EMAP-Implementation-Guide.pdf.
} 
Two training-of-trainers sessions were held in 2015, during which 8 UNHCR staff were trained. EMAP aims to reduce SGBV through accountable male engagement. The approach aims to achieve behavior transformation at the individual level, drawing on an evidence-based, 1 yearlong curriculum. The approach targets both women and men, with a special emphasis on men to enable to identify their role in preventing violence against women, and become women's allies.

This intervention is guided by the voices of women and girls. Their testimony regarding types of violence experienced informs the curriculum used with men. Integral to this implementation is communicating that EMAP activities are not intended to diminish tradition or belief systems, but to encourage practices and beliefs that promote respect for women and non-violence. The intervention is specifically designed for use in humanitarian settings and has been field tested.

UNHCR rolled out EMAP in Dadaab Refugee Camp in Kenya. The project involved 480 men and women, garnered community interest, and has resulted in positive and transformative outcomes. The safety of women and girls became a central concern for the community, safe spaces for women were created, and participants became highly-regarded and considered as role models in the community. Women reported increased cooperation on household responsibilities by their husbands as well as a positive change in husbands' attitudes toward violence. In Dadaab, EMAP was also linked to other programmes, which resulted in enhanced livelihoods for intervention participants.

Challenges with the EMAP intervention in Dadaab have included the following: resistance from the community (especially men) in the forms of denial, victim blaming, justifying reinforcement of harmful norms, and abusive behaviors. Additionally, attrition by men involved in the programme (25\%) was observed due to various reasons. Other challenges include time demands of the process, especially on women volunteers; funding constraints; and staff turnover. In addition, EMAP involves a process of behavior change and is therefore a long-term process which cannot be shortened. In spite of these challenges, overall, EMAP is considered as a cost-effective intervention for influencing positive individual behavior change and addressing IPV and practices harmful to women and girls. It is being introduced in Kakuma Camp, Kenya, and several operations requested support to roll it out.

\section{Engaging Religious Leaders on FGM}

One of the challenges militating against the eradication of FGM is that the practice is deeply embedded in the norms of certain communities which see it as a means of ensuring women's compliance with spiritual standards of (sexual and other forms of) purity. This is particularly observed in Islamic communities where the practice is widespread and has the support of some religious leaders. Work undertaken by UNHCR suggests that the perspective of religious leaders on FGM can be changed though engagement.

In Islamic communities in Ethiopia, UNHRC has explored the use of a dialogue approach to change mindsets among religious clerics,

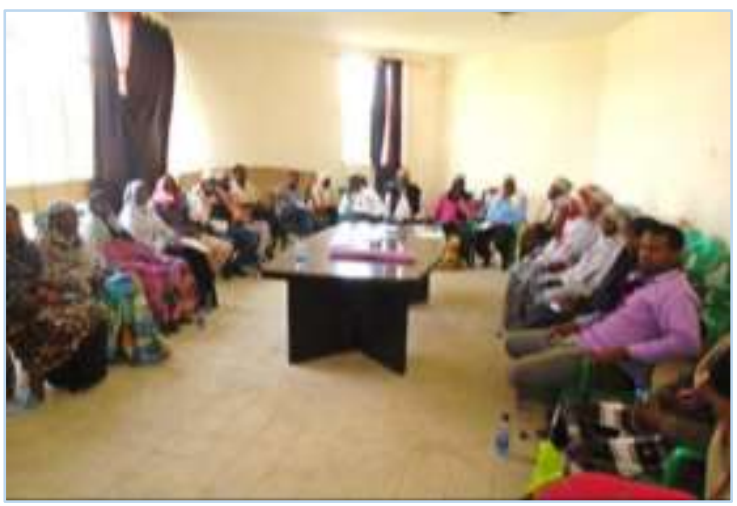

Religious Leaders Discussing FGM/C 
who are invariably male. A series of dialogues were used to establish the lack of reference to FGM in the Quran, and to highlight the violation of human rights and the health consequences that the practice engenders. On the basis of this critical analysis and discussion, a subsequent leaders' forum resulted in clerics making the commitment to raise awareness of the harmful consequences of FGM in mosques, and to cooperate with FGM response efforts by identifying FGM cases, providing spiritual counseling, and guidance and referrals to services. They also committed to reporting their response activities to UNHCR and local authorities.

\section{Providing Safe Environments}

\section{Safe Housing for SGBV Survivors}

Community-led provision of safe environments has emanated from a recognised need for safe housing for female and male SGBV survivors, including LGBTI persons. The HIAS initiative aims to find alternative options for temporary safe housing for such survivors, secure their physical safety, reduce the risk of further abuse, reduce the stigma survivors face, build community capacity to respond to SGBV, and facilitate survivor re-integration into the community after the necessary rehabilitation following an SGBV incident. Recognizing that communities typically have their own approaches to housing SGBV survivors, the HIAS approach to safe housing builds on existing systems by organizing, monitoring, regulating, and resourcing them.

This initiative is being carried out in Nairobi, Kenya, where urban refugees live amongst the local population. HIAS uses a case management approach to assess the appropriate intervention for SGBV survivors. Where safe housing is required, HIAS places survivors in the home of a trained caregiver. Many caregivers that play this role are SGBV survivors themselves, and are therefore sensitized to the situation of other survivors. HIAS matches survivors with caregivers from the same community, with attention to individual characteristics such as gender and sexual orientation. Placement in homes is for a period of no more than 3 months, during which both survivor and caregiver receive food and monetary support from HIAS, coupled with individual therapy sessions for the survivor.

Although still in its early stages, there are indications of positive outcomes from this intervention. Programme observations suggest that the approach improves safety of the survivors through relocating them to a different neighbourhood. The model seems to also facilitate increased community participation in providing support to SGBV survivors, resulting in accelerated recovery of survivors from SGBV related trauma. From the perspective of HIAS, there are indications that the approach has facilitated improved rehabilitation of survivors and mitigated the many challenges involved in managing stand-alone safe housing for SGBV survivors. For instance, living in a normal family environment and being able to interact with others and lead a normal daily life seems to positively impact survivors compared to the use of shelters with an ethos of restriction and confinement.

In addition, there are prospects for building on the current model: There is potential to enhance the capacity of caregivers to provide basic counselling. It might also be beneficial to incorporate caregivers located away from the normal residential areas of refugees, to provide more housing options for high-risk survivors in particular. 
Observed challenges relate to the socioeconomic context of urban refugees. Housing accessed in slum areas tend to be rented homes with severe space constraints. Furthermore, these urban poor contexts have limited resources and livelihoods opportunities. This constrains the options of caregivers and the survivors they endeavor to assist. It also creates placement challenges for survivors with multiple children or dependents.

\section{Women and Girls Empowerment}

UNHCR is exploring a mentorship-based empowerment project to increase female participation and inclusion in girls' formal and informal education and retention, life-skills training, and resilience-building, while advocating for, and supporting, their access to these programmes/resources. Implemented in Kakuma Refugee Camp in north-western Kenya, the intervention targets 1,350 girls and young women ages 12-24, and 400 men. The intervention involves the identification of middle-aged, female

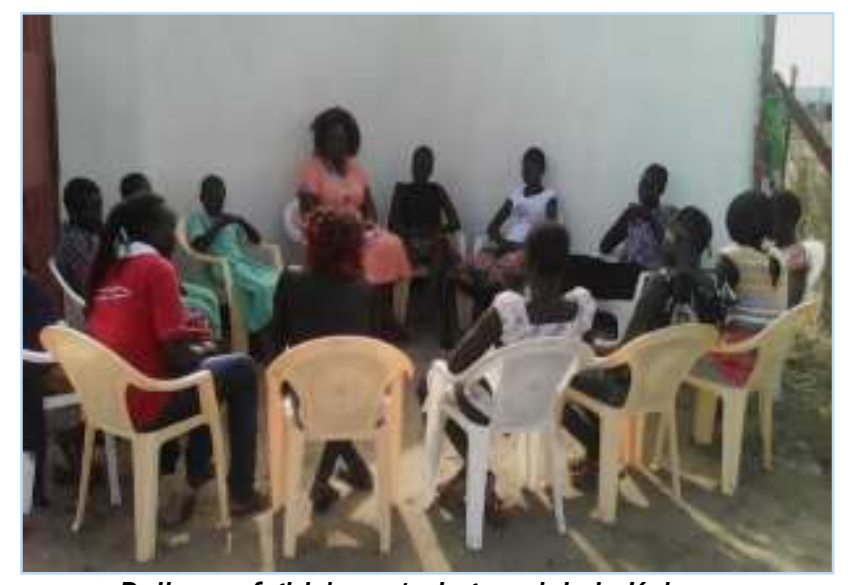

Delivery of girls' mentoring module in Kakuma mentors from within the community (125 mentors already engaged), training of mentors, pairing of mentors to mentees, delivery of an 8-day life-skills and resilience training by mentors to mentees, and regular mentor-mentee monitoring visits and forums. Peer-to-peer support among mentors, and psychosocial support to pregnant teens and teenage mothers are also build in to the model. Girls who express interest in the project are enrolled into the intervention.

Observations to date suggest that there has been increased reporting of violence against girls and women. However, some challenges are worth noting, including the method for selecting intervention participants. Girls are only enrolled in the intervention if they express interest; however, such an intervention is likely to appeal to the least vulnerable girls. To guard against this potential bias, recruitment methods may need to be modified.

Nonetheless, the project is promising on several fronts. It has a male involvement component which entails the training of boys by male mentors, the mentorship of boys with a focus on the protection of girls, and discussion sessions on gender equality and the role of men and boys in ending violence against women and girls. 


\section{GUIDANCE FOR EFFECTIVE ADOPTION OF COMMUNITY ENGAGEMENT IN SGBV PROTECTION AND RESPONSE}

As demonstrated by this compendium of interventions, UNHCR and its partners employ a range of approaches in their efforts to engage communities in SGBV protection and response. A review of these approaches provides important insights, and highlights opportunities for strengthening SGBV programming and influencing positive change.

UNHCR recognises that there are different levels of community engagement (Figure 1$)^{6}$ and that the higher the level of engagement, the greater the likelihood of realizing benefits envisaged from such endeavors. The interventions described in this review employ a relatively comprehensive range of community engagement levels, including community consultation, periodic provision of information, inclusion of communities in particular stages of initiatives, and partnership of agencies with communities in all stages of the process. This range reflects the full spectrum of the levels of community engagement described under the Ladder of Community Engagement: informing, consulting, involving, collaborating and empowering. While initiatives such as SASA!, the Women and Girls Empowerment project, and the 'Zero Tolerance Village Alliance' model could be described as operating at the level of empowering communities, there is considerable scope for UNHCR and its partners to deepen community engagement in the interest of effective and innovative initiatives in line with UNHCR operational standards. ${ }^{7}$ In particular, agencies need to make concerted efforts to ensure that stakeholders are included in project design and evaluation. This means providing roles for communities and other significant stakeholders beyond data provision, to also contributing to priority setting, identification of objectives, analysis, interpretation and evaluation of outcomes.

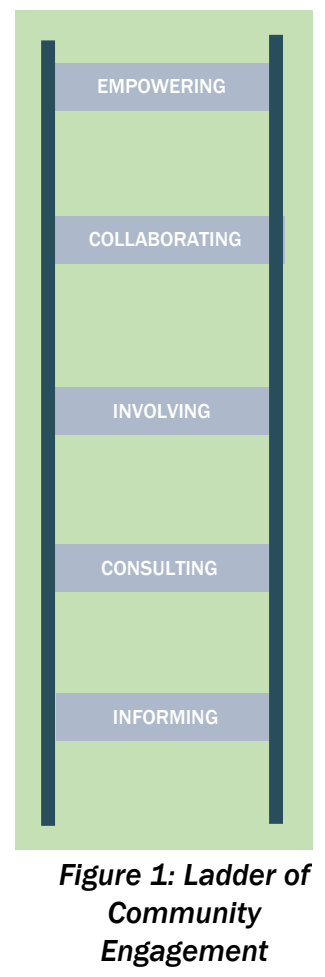

It is important for responders to recognize that communities are not homogenous, and neither are the interests of their subgroups. The question which responders have to consider carefully is who really represents the community. It is for this reason that efforts to engage communities are informed by considerations of how different community groups and interests can be included and addressed. The AGD approach promoted by UNHCR is helpful in this regard. Another enabler would be for the focus of engagement approaches adopted by responders to shift from focusing on the individual to focusing on the collective, with particular concern for inclusivity. Some current initiatives, for instance the Youth Pyramid, SASA!, and community advocacy against FGM, demonstrate the effectiveness of such an inclusive approach in shifting deeply held mindsets which contribute to SGBV.

The SGBV programmes outlined in this document draw on a variety of implementation strategies. In some cases, the programmes are implemented individually by UNHCR. However, more

\footnotetext{
${ }^{6}$ Graph source: P4P LP, Module 3, based on Arnstein's Ladder of Citizen Participation (1969), categories are based on IAP2 Spectrum of Public Participation source: http://c.ymcdn.com/sites/www.iap2.org/resource/resmgr/imported/IAP2\%20Spectrum vertical.pdf.
}

7 See for instance: Practical Guide To The Systematic Use of Standards and Indicators in UNHCR Operations, 2006 http://www.unhcr.org/40eaa9804.pdf 
commonly, UNHCR implements SGBV interventions in partnership with other international organizations or local partners and communities. Within communities, UNHCR programmes show evidence of concerted effort to be inclusive of different categories of the community, including survivors and non-survivors; young and old; male and female; religious and community leaders, as well as other opinion makers. In some cases, such as with regard to the Youth Pyramid model, the design of the approach specifically includes local government authorities. However, greater collaboration with government agencies emerges as a key opportunity to ensure the sustainability of SGBV interventions.

The community-based approach and the Ladder of Community Engagement clearly illustrate that working with communities is a process that requires time and patience before the intended results are achieved. Likewise, addressing SGBV requires considerable investment in prevention and response, coupled with communities that are fully engaged and prepared to take ownership of the issue. This is a call for humanitarian actors to shift from passive participation to empowerment and meaningful participation. The examples reflected in this compendium demonstrate that a huge shift can be made if the right approaches are followed. Multi-year and medium- to long-term planning are a corner stone for successful and sustainable SGBV programme interventions.

A key challenge to community engagement is balancing the interests and priorities of communities with those of the host community and what the responder agencies can realistically offer. There is a need for initiatives to reference and be informed by baseline information and for interventions to have demonstrable effects, as has so far been the case with interventions such as routine screening for SGBV and the 'Zero Tolerance Village Alliance' model. (The effects of the Psychosocial Support Intervention for IPV Survivors in Tanzania and DRC are also being documented). This practice ensures that the specific needs and expectations of communities are clarified and addressed. Nonetheless, the majority of the interventions described in this compilation have not been adequately documented or assessed. This is partly due to the difficulty of conducting rigorous research in humanitarian contexts, which are characterized by emergency conditions, resource constraints, and competing priorities. Still, assessment is key to the identification of appropriate programme interventions which are beneficial to persons of concern, and worthy of the financial investment made by UNHCR.

\section{SGBV Issues Requiring Further Attention}

Ongoing UNHCR programming around SGBV has brought to the fore other important issues which merit attention in order for violence to be holistically addressed in humanitarian contexts in the East, Horn and Great Lakes region. Opportunities for improving community engagement in initiatives relating to these issues are highlighted below.

\section{Early marriage}

Early/child marriage is a form of SGBV which is a serious cause of concern in many humanitarian contexts. It is a form of violence which involves acquiescence of the community; therefore, eliminating this practice in humanitarian contexts must involve strengthening the capacity of community systems to respond to it, while simultaneously addressing resource constraints which lead families to accept child marriage as a way out of their livelihood challenges. For instance, child marriage is used as a means of resettlement: families secure their status by marrying off 
their children (especially daughters) to those with recognized status. Child marriage is a challenge even in countries where the practice is outlawed. Refugee communities are often ignorant of applicable laws in their host country.

Although one early marriage intervention has been documented in this compendium, there is much more to be done on this issue in the region. UNHCR has an important contribution to make in working with communities and authorities to ensure that prevention measures are in place and adequate social, health, and legal support is available for affected children.

Community services have a critical role to play in eliminating child marriage. UNHCR programmes can contribute to increasing community awareness levels; strengthening referral systems for survivors; advocating for increased accessibility and accountability of law enforcement structures; improving the capacity of social welfare and legal officers in the interpretation of the law; and improving the quality and acceptance of comprehensive sexuality education.

\section{Breaking the Silence}

Underreporting of SGBV is a reality which allows such violence to continue undetected. A variety of underlying causes of underreporting must be addressed in the context of programming. These include stigma associated with SGBV; gender-based discrimination and marginalization from resources, including information; and fear of reprisal.

Underreporting of SGBV is also associated with other marginalized groups such as LGBTI and persons engaging in survival sex. In many countries in the region, homosexuality and survival sex are punishable under law. This reality can further foster underreporting by survivors. Advocating for the rights of these groups to live free of abuse therefore emerges as a priority area.

There is a need for UNHCR and its partners to engage communities in breaking the silence which often binds various categories of SGBV survivors. In addition to ongoing women empowerment efforts, UNHCR has the opportunity to scale up approaches which

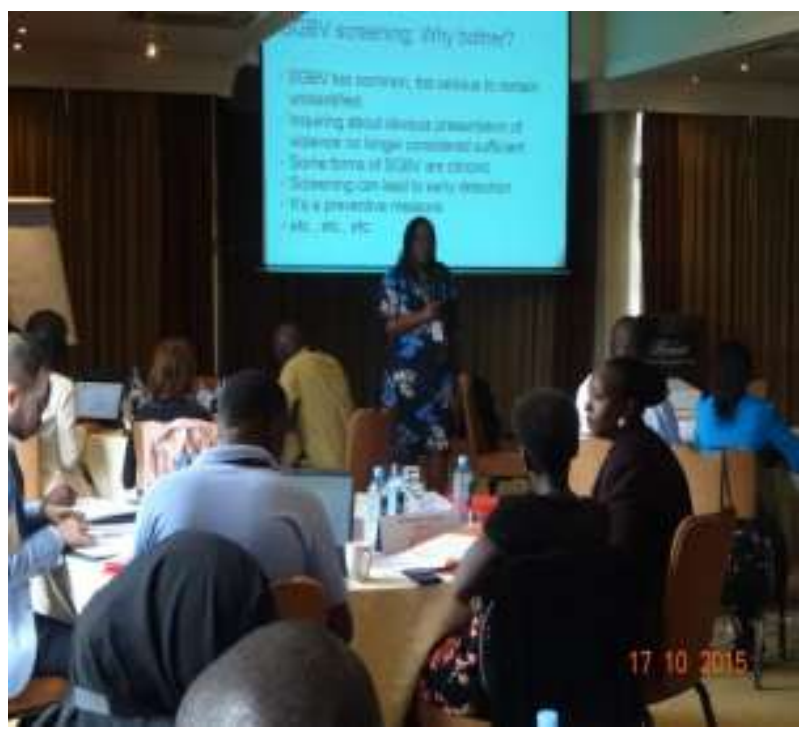

Chi-Chi Undie, presenting findings on SGBV screening. have been seen to yield results. These could include purposeful identification of survivors through routine screening for SGBV, or publicly awarding perpetrators who have demonstrated behavior change (as seen under the Zero Tolerance Village Alliance model). Other promising approaches involve the use of music, dance, and drama to deliver messages on sensitive subjects; and acknowledging and registering women over 18 years in their own right, to reduce their dependence and mitigate intimidation/coercion by male figures in their lives. 


\section{Justice and Legal Systems}

Justice and legal approaches are under-represented among the current initiatives undertaken by UNHCR and its partners in the region. Yet, there are myriad issues requiring redress in the justice and legal systems within which persons of concern operate. For instance, refugee camps are often located in remote areas with limited resources allocated to the legal aspects of SGBV response. Legal procedures are often lengthy, and plural legal systems might result in the nonapplication of international human rights standards (by traditional courts, for instance), at the expense of survivors. These and other legal system challenge hamper SGBV reporting by survivors.

Nonetheless, some promising initiatives are observed which can be investigated further with the view to testing and scaling up, as appropriate. For instance, mobile courts are a key response, and are currently being applied in some UNHCR operations. These increase accessibility of justice for survivors and entail strong community involvement in justice delivery. Challenges to be addressed with this approach include failure to appear by survivors or withdrawal of cases. In Kenya, efforts are underway to improve linkages between traditional and legal courts. In Burundi and Djibouti, UNHCR supports SGBV committees, which refer issues to courts. An encouraging initiative is underway in Uganda, where selected willing communities receive and rehabilitate perpetrators upon release. UNHCR is supporting these efforts with livelihoods projects for former perpetrators.

Recommended areas for intervention by UNHCR and partners include: sensitizing people of concern to court processes; making court processes survivor-friendly (e.g., through the introduction of gender desks to accelerate the prosecution of SGBV cases); training of paralegals in order to reduce reliance on lawyers; introducing civil action in order to obtain compensation for survivors; and engaging perpetrators. The engagement of perpetrators is receiving gradual recognition as a key area to address in SGBV prevention and response. Such engagement could entail the protection of perpetrators against whom unlawful actions have been taken particularly, minors who perpetrate SGBV.

\section{Economic violence}

Although usually overlooked, economic violence is emerging as an aspect of gendered violence which reinforces other violence forms (e.g., physical, sexual, or emotional violence). UNHCR recognizes the need to enhance understanding of economic violence and to design interventions to address it.

To mitigate economic IPV, UNHCR currently implements a range of interventions to empower women and girls economically. In Tanzania, for instance, UNHCR registers women as heads of household. In Uganda, where polygamous marriages are observed among persons of concern, UNHCR beneficiary schemes recognize each woman in a marital union, in addition to the man. A 'do no harm' lens must be employed with this approach, however, to mitigate any unintended social repercussions.

To address non-partner economic violence, UNHCR has explored the application of cash-based interventions instead of distribution of food or other non-food items. Some distributed items may not be viewed as a priority by persons of concern. In such cases, these items may end up being undersold - a problem which cash can help to circumvent. Cash-based interventions can also 
empower households by affording them the opportunity to go through the process of prioritizing their needs and enabling them to exercise freedom of choice. Further, as cash comes presents no expiration concerns and can be used over a longer period of time, it reduces involvement in risk behavior such as survival sex. The privacy associated with electronic cash distributions may reduce the exposure of women and girls to SGBV, unlike food distribution which is public, making it easier for perpetrators to identify females who have received food. This includes break-ins experienced after receiving food parcels. Nonetheless, there is also evidence that cash-based interventions appear to reduce domestic violence, while simultaneously increasing other forms of violence.

Although food distribution is preferred in some cases where markets are poorly-developed, UNHCR is increasingly exploring cash-based interventions. The focus of these interventions is on cash for protection rather than just as the modality of transfer. Concerted engagement with communities is required in order to identify the most appropriate approaches, for instance, in the case of the elderly with low technical knowledge. Engagement with communities also iron out modalities for transfer to money in order to 'do no harm'. Similarly, delicate modalities must be established in the case unaccompanied children. Community consultation is at community level but interventions at individual level, including training on the use of cash. 


\section{FINAL THOUGHTS}

This compendium makes available a variety of research findings and approaches to addressing SGBV to UNHCR partners and programmes. The interventions outlined are the outcome of contributions from government, NGOs, research organizations, and UNHCR staff. Country programmes have the opportunity to make use of some or all of the innovations described, depending on prevailing conditions. Emerging areas of interest by UNHCR country programmes (as indicated by participants during the meeting) are mapped in Annex 3. The highlighted interventions are at various levels of maturity in humanitarian contexts, and while some have been documented and assessed, others remain promising and worthy of assessment.

The meeting unveiled participants' keen interest in deepening their current efforts on community engagement in SGBV protection and response. This will require support, however. It is particularly important for secure funding to be allocated to facilitate programme planning and implementation. In addition to financial resources, the following needs must be taken into account:

- Partnerships with a variety of stakeholders whose contribution can add value to the work of UNHCR programmes. These include local government agencies, service providers, implementing partners, civil society organizations, law enforcement agencies, traditional authorities, and community members (both host community and refugee community members).

- Training and capacity-building of staff or volunteers implementing SGBV initiatives on the ground. Capacity-building for 'trainers of trainers,' paralegals, and trauma counselors is of paramount importance, as is increasing the numbers of such staff/volunteers.

- Awareness-raising, sensitization, and advocacy within communities to address SGBV under-reporting in communities.

- The creation of more safe spaces for survivors to access support.

- Clarifying the range of psychological support needed by SGBV survivors, and developing (and delivering) training curricula accordingly. (Meeting discussions confirmed that counseling for survivors in mostly 'non-specific,' with little known about the actual content of such counseling).

- Maximizing the use of host country laws, regulations, and government networks for SGBV protection and response. Agencies can also make more effective use of country legal frameworks to bridge the gap between traditional practices which contribute to SGBV and international human rights conventions and norms intended to protect and safeguard the rights of all persons to live free from violence and abuse.

- Developing or strengthen appropriate responses for populations that receive less (or require more) attention in programming, including unaccompanied minors, male SGBV survivors, LGBTI persons subjected to SGBV, and perpetrators.

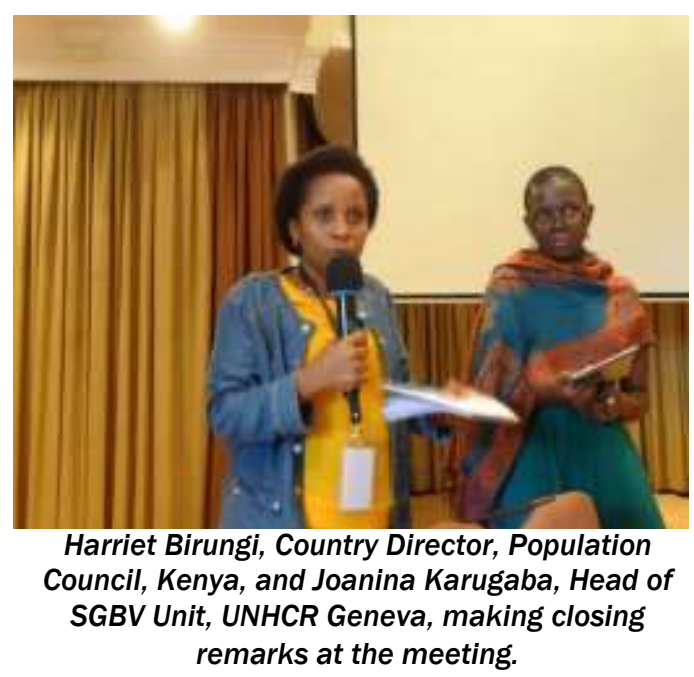




\section{Annex 1: Workshop Agenda}

\begin{tabular}{|c|c|c|}
\hline \multicolumn{3}{|c|}{ Monday, 17 October 2016} \\
\hline & Moderator: Joanina Karugaba & \\
\hline 08.45-09.00 & Registration, Welcome & Joyce Ombeva \\
\hline 09.00-09:45 & Introduction and Workshop Objectives & $\begin{array}{l}\text { Zahra Mirghani } \\
\text { Chi-Chi Undie }\end{array}$ \\
\hline 09:45-10:00 & Populations Council: Who We Are and What We Do & Harriet Birungi \\
\hline 10:10-10:45 & $\begin{array}{l}\text { Overview of UNHCR Strategy and evaluation } \\
\text { Community Engagement in addressing SGBV Prevention } \\
\text { and Response }\end{array}$ & $\begin{array}{l}\text { Joanina Karugaba } \\
\text { Zahra Mirghani }\end{array}$ \\
\hline $10.45-11.00$ & \multicolumn{2}{|l|}{ Coffee Break } \\
\hline 11:00-12:15 & $\begin{array}{l}\text { Screening for Sexual and Gender-Based Violence in } \\
\text { Emergency Settings: An Assessment of Feasibility (Uganda) } \\
\text { Population Council, Africa Humanitarian Action } \\
\text { Reflections, Discussion, Take-Aways }\end{array}$ & $\begin{array}{l}\text { Chi-Chi Undie } \\
\text { Lillian Maate }\end{array}$ \\
\hline $12.15-13: 00$ & Psychosocial Interventions Research- Tanzania (Kasulu) & Elizabeth Morrissey \\
\hline $13.00-14: 00$ & \multicolumn{2}{|l|}{ Lunch } \\
\hline 14:00- 15:00 & $\begin{array}{l}\text { The Zero Tolerance Research Village Alliance Model: An } \\
\text { Assessment of Effectiveness (Uganda) } \\
\text { Population Council, Thohoyandou Victim Empowerment } \\
\text { Programme, Lutheran World Federation } \\
\text { Reflections, Discussion, Take-Aways }\end{array}$ & $\begin{array}{l}\text { Chi-Chi Undie } \\
\text { Fiona Nicholson } \\
\text { Prosmolly Ayebale }\end{array}$ \\
\hline 15.00-15:15 & Coffee Break & \\
\hline $15.15-16.15$ & $\begin{array}{l}\text { Community Based Protection Policy \& } \\
\text { Key principles for engaging communities } \\
\text { UNHCR Geneva }\end{array}$ & Nicholas Martin-Achard \\
\hline $16: 15-17.15$ & $\begin{array}{l}\text { Ladder of Community Engagement } \\
\text { UNHCR Regional Services Centre }\end{array}$ & $\begin{array}{l}\text { Zahra Mirghani } \\
\text { Nicholas Martin-Achard }\end{array}$ \\
\hline 17:15-17:20 & Remarks and Closure of Day One & Joanina Karugaba \\
\hline \multicolumn{3}{|c|}{ Tuesday, 18 October 2016} \\
\hline \multicolumn{3}{|c|}{ Moderator: Zahra Mirghani } \\
\hline $09.00-09.15$ & Recap of Day One & Sue Mbaya \\
\hline $09.15-10.30$ & $\begin{array}{l}\text { 1. Engaging Men in Accountable Practice (Dadaab, Kenya) } \\
\text { 2. Men Engagement (S. Sudan) } \\
\text { 3. Boys engagement (Sudan) } \\
\text { Reflections, Discussion, Take-Aways }\end{array}$ & $\begin{array}{l}\text { Samuel Kotonya } \\
\text { Regina Daniel } \\
\text { Ida Haroun Karbous }\end{array}$ \\
\hline $10.30-10.45$ & \multicolumn{2}{|l|}{ Coffee Break } \\
\hline $10.45-11.15$ & $\begin{array}{l}\text { 1. Safe Housing for Survivors (Kenya) } \\
\text { Reflections, Discussion, Take-Aways }\end{array}$ & $\begin{array}{l}\text { Doris Kawira - HIAS } \\
\text { TBC }\end{array}$ \\
\hline $11.15-12.30$ & $\begin{array}{l}\text { FGM Video } \\
\text { 1. Community advocacy against FGM (Dadaab, Kenya) } \\
\text { 2. Religious leaders and FGM (Ethiopia) } \\
\text { Reflections, Discussion, Take-Aways }\end{array}$ & $\begin{array}{l}\text { Hassan Aden } \\
\text { Mulugeta Tesfaye Hailu }\end{array}$ \\
\hline $12.30-13.30$ & Lunch & \\
\hline
\end{tabular}




\begin{tabular}{|c|c|c|}
\hline $13.30-14.30$ & $\begin{array}{l}\text { 1. Youth Pyramid (Adjumani Uganda) } \\
\text { 2. Outreach Volunteers Urban Program (Kenya) } \\
\text { Reflections, Discussion, Take-Aways }\end{array}$ & $\begin{array}{l}\text { Prosmolly Ayebale - LWF } \\
\text { Karen Kotut-Kimuge }\end{array}$ \\
\hline $14.30-15.30$ & SASA! Approach: A Facilitated Discussion & Zahra Mirghani \\
\hline $15.30-15.45$ & \multicolumn{2}{|l|}{ Coffee Break } \\
\hline $15.45-17.00$ & $\begin{array}{l}\text { Group work on thematic areas of SGBV } \\
\text { Reflections, Discussion, Take-Aways }\end{array}$ & Zahra Mirghani \\
\hline $17.00-17.15$ & Remarks and Closure of Day Two & Harriet Birungi \\
\hline \multicolumn{3}{|c|}{ Wednesday, 19 October 2016} \\
\hline \multicolumn{3}{|c|}{ Moderator: Mike Mbizvo } \\
\hline 09.00-09.15 & Recap of Day Two & Chi-Chi Undie \\
\hline 09.15-10.15 & $\begin{array}{l}\text { 1. Women and Girls Empowerment (Kakuma) } \\
\text { 2. Survival sex (video) } \\
\text { Reflections, Discussion, Take-Aways }\end{array}$ & $\begin{array}{l}\text { Robin Masinde Lyambila } \\
\text { Zahra Mirghani }\end{array}$ \\
\hline $10.15-10.30$ & \multicolumn{2}{|l|}{ Coffee Break } \\
\hline 10.30-11.15 & Sexual Minorities (LGBTI) (video) & Nicolas Martin-Archard \\
\hline $11.15-12.30$ & $\begin{array}{l}\text { Community Engagement of Sexual Minorities: } \\
\text { Group Work } \\
\text { Presentation of Group Work }\end{array}$ & Nicolas Martin-Archard \\
\hline $12.30-13.30$ & \multicolumn{2}{|l|}{ Lunch } \\
\hline $13.30-15.00$ & $\begin{array}{l}\text { Way Forward: Opportunities and Possibilities for Annual } \\
\text { Program Planning }\end{array}$ & Zahra Mirghani \\
\hline $15.00-15.15$ & \multicolumn{2}{|l|}{ Coffee Break } \\
\hline $15.15-15.45$ & Evaluation and closure & $\begin{array}{l}\text { Joanina Karugaba } \\
\text { Harriet Birungi }\end{array}$ \\
\hline
\end{tabular}




\section{Annex 2: Attendance list}

\begin{tabular}{|c|c|c|}
\hline Name & Designation & Country \\
\hline \multicolumn{3}{|c|}{ AFRICA HUMANITARIAN ACTION } \\
\hline Alex Amanyire & Clinical Officer & Uganda \\
\hline Lillian Maate & Project Coordinator (SGBV) & Uganda \\
\hline \multicolumn{3}{|c|}{ HIAS REFUGEE TRUST OF KENYA } \\
\hline Doris Kawira & Protection Programme Manager & Kenya \\
\hline Elizabeth Waruiru & Protection Officer & Kenya \\
\hline \multicolumn{3}{|c|}{ INTERNATIONAL RESCUE COMMITTEE } \\
\hline Christine Kivuyo & WPE Manager & Kenya \\
\hline \multicolumn{3}{|c|}{ LUTHERAN WORLD FEDERATION } \\
\hline Prosmolly Ayebale & GBV Protection Coordinator & Uganda \\
\hline Geofrey Sabiiti & GBV Officer & Uganda \\
\hline \multicolumn{3}{|c|}{ OFFICE OF THE PRIME MINISTER (REFUGEES DEPARTMENT), UGANDA } \\
\hline Peace Birungi & Community Services Assistant & Uganda \\
\hline Darlson Kusasira & Community Services Officer & Uganda \\
\hline David Mugenyi & Camp Commandant & Uganda \\
\hline \multicolumn{3}{|c|}{ POPULATION COUNCIL } \\
\hline Harriet Birungi & Country Director and Senior Associate & Kenya \\
\hline Rosemary Maeri & Research Assistant & Kenya \\
\hline Sue Mbaya & Consultant & Kenya \\
\hline Janet Munyasya & Program Coordinator & Kenya \\
\hline Hellen Murugi & Research Assistant & Kenya \\
\hline Joyce Ombeva & Program Coordinator & Kenya \\
\hline Wesley Onsongo & Research Assistant & Kenya \\
\hline Thomas Saria & Research Assistant & Kenya \\
\hline Chi-Chi Undie & Senior Associate & Kenya \\
\hline Jane Harriet Namwebya & Consultant & Uganda \\
\hline Michael Mbizvo & Country Director and Senior Associate & Zambia \\
\hline \multicolumn{3}{|c|}{ THOHOYANDOU VICTIM EMPOWERMENT PROGRAMME } \\
\hline Tshilidzi Masikhwa & Operations Manager, TVEP & South Africa \\
\hline Fiona Nicholson & Executive Director, TVEP & South Africa \\
\hline \multicolumn{3}{|c|}{ UNHCR } \\
\hline Christine Irambona & National Community Services Officer & Burundi \\
\hline Sylvie Niyibizi & National Community Services Officer & Burundi \\
\hline
\end{tabular}




\begin{tabular}{|c|c|c|}
\hline Name & Designation & Country \\
\hline Samia Abdoulkarim Abdallah & Senior Protection Assistant & Djibouti \\
\hline Sarah Tekle Andemariam & Protection Associate & Eritrea \\
\hline Mulugeta Tesfaye Hailu & Assistant Protection Officer & Ethiopia \\
\hline Rana Milhem & Community Based Protection Officer & Ethiopia \\
\hline Hassan Aden & Community Based Protection Associate & Kenya \\
\hline Samuel Kotonya & Assistant Protection Officer & Kenya \\
\hline Karen Kotut & Legal Associate (SGBV), UNHCR & Kenya \\
\hline Robin Masinde Lyambila & Community Services Assistant & Kenya \\
\hline Zahra Mirghani & Regional Senior Protection Officer & Kenya \\
\hline Jean Bosco Nimubona & Community Based Protection & Kenya \\
\hline Fernanda Varela & Associate Community Services Officer & Kenya \\
\hline Sidra Anwar & Associate SGBV Officer & Rwanda \\
\hline Specioze Batamuliza & Associate Protection Officer & Rwanda \\
\hline Khadra Ali & Community Services Assistant & Somalia \\
\hline Amina Osman Haji & Protection Associate & Somalia \\
\hline Shamso Haji-Mohamed & Senior Protection Assistant & Somalia \\
\hline Khamis Wude Daniel & Community Services Associate & South Sudan \\
\hline Meriam Moletsane & Community Services Officer & South Sudan \\
\hline Maria Ellazim Ahmed & Community Services Associate & Sudan \\
\hline Aida Karbous & Senior Community Services Assistant & Sudan \\
\hline Joanina Karugaba & Senior SGBV Advisor & Switzerland \\
\hline Nicholas Martin-Achard & Community-Based Protection Advisor & Switzerland \\
\hline Elizabeth Morrissey & Associate Protection Officer & Tanzania \\
\hline Elsa Bokhre & Senior Protection Officer & Uganda \\
\hline
\end{tabular}




\section{Annex 3: Compendium of SGBV Protection and Response Approaches}

\begin{tabular}{|c|c|c|c|c|c|c|c|}
\hline $\begin{array}{l}\text { Initiative } \\
\text { /Approach }\end{array}$ & $\begin{array}{l}\text { Reference } \\
\text { Organization } \\
\text { (s) }\end{array}$ & $\begin{array}{l}\text { Types of } \\
\text { Violence } \\
\text { Addressed }\end{array}$ & Main Target(s) & $\begin{array}{l}\text { Key Words/ } \\
\text { Cross Cutting } \\
\text { Themes }\end{array}$ & $\begin{array}{l}\text { Approach } \\
\text { Used }\end{array}$ & $\begin{array}{l}\text { Extent of } \\
\text { Community } \\
\text { Engagement }\end{array}$ & $\begin{array}{l}\text { Assessed } \\
Y / N\end{array}$ \\
\hline $\begin{array}{l}\text { Screening for } \\
\text { Sexual and } \\
\text { Gender } \\
\text { based } \\
\text { Violence in } \\
\text { Emergency } \\
\text { Settings }\end{array}$ & $\begin{array}{l}\text { UNHCR } \\
\text { Population } \\
\text { Council }\end{array}$ & $\begin{array}{l}\text { - IPV (physical, } \\
\text { psychologica } \\
\text { I and sexual) } \\
\text { - Non-partner } \\
\text { sexual } \\
\text { violence }\end{array}$ & Women & $\begin{array}{l}\text { - Sexual and } \\
\text { reproductive } \\
\text { health } \\
\text { - Rape } \\
\text { - IPV }\end{array}$ & $\begin{array}{l}\text { - SGBV } \\
\text { prevention } \\
\text { - Survivor } \\
\text { care }\end{array}$ & Consulting & $\mathrm{Y}$ \\
\hline $\begin{array}{l}\text { Psycho-social } \\
\text { Interventions } \\
\text { Approach }\end{array}$ & UNHCR & - IPV & $\begin{array}{l}\text { SGBV } \\
\text { survivors }\end{array}$ & $\begin{array}{l}\text { - Post-traumatic } \\
\text { stress } \\
\text { - Cognitive } \\
\text { processing } \\
\text { therapy (CPT) } \\
\text { - Cognitive } \\
\text { behavioral } \\
\text { therapy (CBT) }\end{array}$ & - Survivor care & Involving & Underway \\
\hline $\begin{array}{l}\text { Zero } \\
\text { Tolerance } \\
\text { Village Model }\end{array}$ & $\begin{array}{l}\text { Thohoyandou } \\
\text { Victim } \\
\text { Empowerment } \\
\text { Programme }\end{array}$ & $\begin{array}{l}\text { - SGBV (non- } \\
\text { specific) }\end{array}$ & Communities & $\begin{array}{l}\text { - Achievement } \\
\text { motivation } \\
\text { theory } \\
\text { - Labelling } \\
\text { theory }\end{array}$ & $\begin{array}{l}\text { - Community } \\
\text { mobilization } \\
\text { (changing } \\
\text { social norms) }\end{array}$ & Empowering & Y \\
\hline $\begin{array}{l}\text { Engaging } \\
\text { Men in } \\
\text { Accountable } \\
\text { Practices }\end{array}$ & $\begin{array}{l}\text { Widespread } \\
\text { use }\end{array}$ & $\begin{array}{l}\text { - SGBV (non- } \\
\text { specific) }\end{array}$ & Men and boys & $\begin{array}{l}\text { - Behaviour } \\
\text { transformatio } \\
n\end{array}$ & $\begin{array}{l}\text { - Community } \\
\text { mobilization } \\
\text { - Personnel } \\
\text { training / } \\
\text { sensitization }\end{array}$ & Involving & Y \\
\hline $\begin{array}{l}\text { Safe Housing } \\
\text { for SGBV } \\
\text { Survivors }\end{array}$ & HIAS & - IPV & $\begin{array}{l}\text { SGBV } \\
\text { survivors } \\
\text { LGBTI persons }\end{array}$ & $\begin{array}{l}\text { - Housing } \\
\text { - Reducing } \\
\text { stigma } \\
\text { - Urban context }\end{array}$ & - Survivor care & Involving & $\mathrm{N}$ \\
\hline $\begin{array}{l}\text { Youth } \\
\text { Pyramid } \\
\text { Structure }\end{array}$ & $\begin{array}{l}\text { Lutheran } \\
\text { World } \\
\text { Federation }\end{array}$ & $\begin{array}{l}\text { - SGBV (non- } \\
\text { specific) }\end{array}$ & $\begin{array}{l}\text { Young people } \\
\text { both SGBV } \\
\text { penetrators } \\
\text { and survivors }\end{array}$ & $\begin{array}{l}\text { - Anti-SGBV } \\
\text { youth groups } \\
\text { - Peer educators }\end{array}$ & $\begin{array}{l}\text { - Community } \\
\text { mobilization } \\
\text { - Livelihood } \\
\text { initiative } \\
\text { - SGBV } \\
\text { prevention }\end{array}$ & Collaborating & $\mathrm{N}$ \\
\hline $\begin{array}{l}\text { Youth } \\
\text { Engagement } \\
\text { in SGBV } \\
\text { Prevention } \\
\text { and } \\
\text { Response } \\
\text { Project }\end{array}$ & UNHCR & $\begin{array}{l}\text { - Child } \\
\text { marriage } \\
\text { - Violence } \\
\text { against } \\
\text { children }\end{array}$ & Young people & - Child protection & $\begin{array}{l}\text { - Community } \\
\text { mobilization } \\
\text { - SGBV } \\
\text { prevention }\end{array}$ & Involving & $\mathrm{N}$ \\
\hline $\begin{array}{l}\text { Outreach } \\
\text { Volunteers } \\
\text { Programme }\end{array}$ & UNHCR & $\begin{array}{l}\text { - SGBV (non- } \\
\text { specific) }\end{array}$ & Communities & $\begin{array}{l}\text { - Peer educators } \\
\text { - Urban context } \\
\text { - Community } \\
\text { based } \\
\text { psychosocial } \\
\text { support }\end{array}$ & $\begin{array}{l}\text { - Survivor care } \\
\text { - Community } \\
\text { mobilization }\end{array}$ & Involving & $\mathrm{N}$ \\
\hline $\begin{array}{l}\text { SASA! } \\
\text { Approach }\end{array}$ & Raising Voices & $\begin{array}{l}\text { SGBV non- } \\
\text { specific }\end{array}$ & Women & $\begin{array}{l}\text { - Behavior } \\
\text { change } \\
\text { - Power relations } \\
\text { - Evidence based } \\
\text { training toolkits }\end{array}$ & $\begin{array}{l}\text { - Community } \\
\text { mobilization }\end{array}$ & Involving & $\mathrm{N}$ \\
\hline $\begin{array}{l}\text { Women and } \\
\text { Girls } \\
\text { Empowerme } \\
\text { nt Approach }\end{array}$ & UNHCR & $\begin{array}{l}\text { SGBV against } \\
\text { girls }\end{array}$ & $\begin{array}{l}\text { Girls and } \\
\text { women }\end{array}$ & $\begin{array}{l}\text { - Mentorship- } \\
\text { based } \\
\text { empowerment } \\
\text { - Access to } \\
\text { services. These } \\
\text { include }\end{array}$ & $\begin{array}{l}\text { - Community } \\
\text { mobilization } \\
\text { and } \\
\text { empowerme } \\
\text { nt }\end{array}$ & Involving & $\mathrm{N}$ \\
\hline
\end{tabular}




\begin{tabular}{|c|c|c|c|c|c|c|c|}
\hline $\begin{array}{l}\text { Initiative } \\
\text { /Approach }\end{array}$ & $\begin{array}{l}\text { Reference } \\
\text { Organization } \\
\text { (s) }\end{array}$ & $\begin{array}{l}\text { Types of } \\
\text { Violence } \\
\text { Addressed }\end{array}$ & Main Target(s) & $\begin{array}{l}\text { Key Words/ } \\
\text { Cross Cutting } \\
\text { Themes }\end{array}$ & $\begin{array}{l}\text { Approach } \\
\text { Used }\end{array}$ & $\begin{array}{l}\text { Extent of } \\
\text { Community } \\
\text { Engagement }\end{array}$ & $\begin{array}{l}\text { Assessed } \\
Y / N\end{array}$ \\
\hline & & & & $\begin{array}{l}\text { education and } \\
\text { retention (both } \\
\text { formal and } \\
\text { informal), life } \\
\text { skills training } \\
\text { and resilience } \\
\text { building among } \\
\text { girls }\end{array}$ & $\begin{array}{l}\text { - Personnel } \\
\text { training / } \\
\text { sensitization }\end{array}$ & & \\
\hline $\begin{array}{l}\text { Protection } \\
\text { Learning } \\
\text { Programme } \\
\text { - Anti FGM } \\
\text { Initiative }\end{array}$ & UNHCR & FGM & $\begin{array}{l}\text { Community } \\
\text { members }\end{array}$ & $\begin{array}{l}\text { - Community } \\
\text { dialogue } \\
\text { - Cultural and } \\
\text { religious norms } \\
\text { and practices }\end{array}$ & $\begin{array}{l}\text { - Survivor care } \\
\text { intervention } \\
\text { Community } \\
\text { mobilization } \\
\text { initiatives }\end{array}$ & Involving & $\mathrm{N}$ \\
\hline $\begin{array}{l}\text { Engaging } \\
\text { Religious } \\
\text { Leaders on } \\
\text { FGM }\end{array}$ & UNHCR & FGM & $\begin{array}{l}\text { Community, } \\
\text { leaders, } \\
\text { religious } \\
\text { leaders }\end{array}$ & $\begin{array}{l}\text { - Community } \\
\text { dialogue } \\
\text { - Cultural and } \\
\text { religious norms } \\
\text { and practices }\end{array}$ & $\begin{array}{l}\text { - Community } \\
\text { mobilization } \\
\text { initiatives }\end{array}$ & Consulting & $\mathrm{N}$ \\
\hline
\end{tabular}




\section{Annex 4: Possible Areas of Interest for anti-SGBV initiatives}

\begin{tabular}{|c|c|c|c|c|c|c|c|c|c|c|c|c|c|}
\hline & & 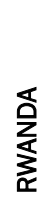 & 芯 & 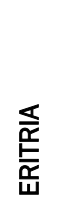 & 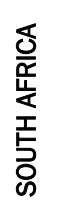 & $\frac{\overleftarrow{a}}{\frac{\square}{0}}$ & 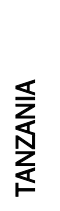 & 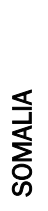 & 突 & $\frac{\overline{5}}{\underline{\underline{a}}}$ & 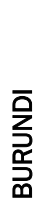 & 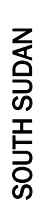 & 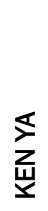 \\
\hline \multirow{14}{*}{ 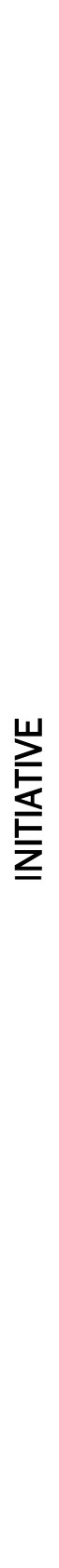 } & $\begin{array}{l}\text { Women and Youth } \\
\text { Empowerment }\end{array}$ & & & & & & & & & & & & \\
\hline & $\begin{array}{l}\text { Zero Tolerance Research } \\
\text { Village Alliance Model }\end{array}$ & & & & & & & & & & & & \\
\hline & $\begin{array}{l}\text { Outreach Volunteers } \\
\text { Programme }\end{array}$ & & & & & & & & & & & & \\
\hline & $\begin{array}{l}\text { Screening for SGBV in } \\
\text { Emergency Settings }\end{array}$ & & & & & & & & & & & & \\
\hline & $\begin{array}{l}\text { Engaging Men in Accountable } \\
\text { Practices }\end{array}$ & & & & & & & & & & & & \\
\hline & SASA! Approach & & & & & & & & & & & & \\
\hline & Programming for Sex Workers & & & & & & & & & & & & \\
\hline & $\begin{array}{l}\text { Community Safe Housing for } \\
\text { SGBV Survivors }\end{array}$ & & & & & & & & & & & & \\
\hline & $\begin{array}{l}\text { Women Mentorship } \\
\text { Programme }\end{array}$ & & & & & & & & & & & & \\
\hline & Access to Justice Programme & & & & & & & & & & & & \\
\hline & Youth Pyramid Structure & & & & & & & & & & & & \\
\hline & $\begin{array}{l}\text { Psycho-social Interventions } \\
\text { Approach }\end{array}$ & & & & & & & & & & & & \\
\hline & $\begin{array}{l}\text { Protection Learning } \\
\text { Programme - Anti FGM } \\
\text { Initiative }\end{array}$ & & & & & & & & & & & & \\
\hline & $\begin{array}{l}\text { Engaging Religious Leaders on } \\
\text { FGM }\end{array}$ & & & & & & & & & & & & \\
\hline
\end{tabular}


A Compendium of Interventions on Community SGBV Prevention and Response in the East \& Horn of Africa and the Great Lakes Region (2017)

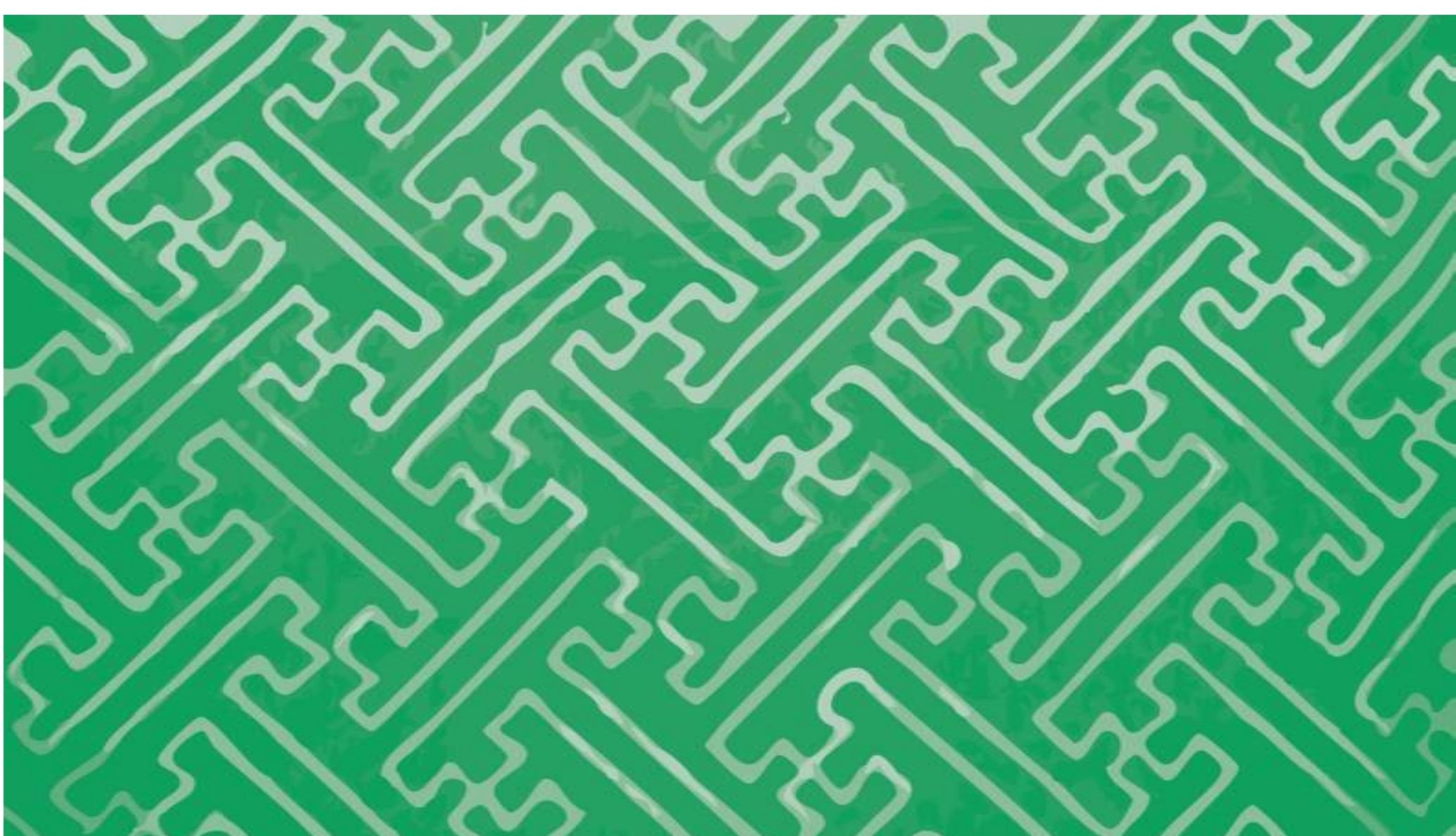

